Wright State University

CORE Scholar

$11-1-2000$

\title{
Comparison of Coastal Fringe and Interior Forests as Reserves for Marbled Murrelets on Vancouver Island
}

\author{
Alan E. Burger \\ Volker Bahn \\ Wright State University - Main Campus, volker.bahn@wright.edu \\ Angeline R.M. Tillmanns
}

Follow this and additional works at: https://corescholar.libraries.wright.edu/biology

Part of the Ecology and Evolutionary Biology Commons

\section{Repository Citation}

Burger, A. E., Bahn, V., \& Tillmanns, A. R. (2000). Comparison of Coastal Fringe and Interior Forests as Reserves for Marbled Murrelets on Vancouver Island. The Condor, 102 (4), 915-920.

https://corescholar.libraries.wright.edu/biology/24

This Article is brought to you for free and open access by the Biological Sciences at CORE Scholar. It has been accepted for inclusion in Biological Sciences Faculty Publications by an authorized administrator of CORE Scholar. For more information, please contact library-corescholar@wright.edu. 


\title{
COMPARISON OF COASTAL FRINGE AND INTERIOR FORESTS AS RESERVES FOR MARBLED MURRELETS ON VANCOUVER ISLAND ${ }^{1}$
}

\author{
Alan E. Burger, Volker Bahn and Angeline R. M. Tillmanns \\ Department of Biology, University of Victoria, Victoria, British Columbia, V8W 3N5, Canada, \\ e-mail: aburger@uvvm.uvic.ca
}

\begin{abstract}
Much of the protected habitat available to the threatened Marbled Murrelet Brachyramphus marmoratus and other old-growth associated species in the Pacific Northwest is in narrow strips along the coast (e.g., parks and scenic fringes). Using data over two years from three watersheds on southwest Vancouver Island, we show that such shoreline strip forests represent suboptimal habitat for murrelets. Murrele detections, including circling and subcanopy behaviors, were significantly lower at 30 coastal stations (20-250 $\mathrm{m}$ from the shoreline edge) than at 30 interior stations (1.5-21.0 km inland). Densities of predators were significantly higher at the coastal stations. The coastal trees were of similar mean height and diameter, but they had lower structural diversity and provided fewer and less suitable (thinner epiphyte cover on large boughs) nesting platforms than trees in the interior. When possible, reserves for Marbled Murrelets should be placed in interior and not shoreline forests.
\end{abstract}

Key words: Brachyramphus marmoratus, coastal forests, Marbled Murrelet, nesting, Vancouver Island.

Many parks and other protected areas along the coast of the Pacific Northwest consist of narrow strips of old-growth forest bordering the ocean. These strips serve as recreation areas and "scenic fringes" in areas frequented by tourists, or protect sensitive shoreline areas and fish spawning sites when clearcut logging occurs. Such strips of forest are usually included in the inventory of habitat available for the Marbled Murrelet Brachyramphus marmoratus, and other old-growth associated species. There is evidence from the Queen Charlotte Islands (Rodway et al. 1991), Vancouver Island (Rodway and Regehr 1999), and Washington state (Hamer 1995) that shoreline fringe forests might not provide optimal nest habitats for murrelets. In this paper we specifically address this issue by comparing murrelet detection rates, habitat measures, and densities of predators at shoreline and interior sites in three watersheds on Vancouver Island.

Marbled Murrelets are listed as threatened through most of their range in the Pacific Northwest, apart from Alaska (Ralph et al. 1995). Loss of nesting habitat through logging of old-growth forest is the greatest threat (Ralph et al. 1995, Nelson 1997), but increased predation at nests, due to edge-effects created by clear-

\footnotetext{
${ }^{1}$ Received 31 January 2000. Accepted 19 July 2000.
}

cut logging, is an additional problem (Nelson and Hamer 1995, Manley 1999). At sea, oil pollution, gill nets, and aquaculture pose problems for murrelets (Ralph et al. 1995). The high economic value of the forests in which murrelets nest ensures conflicts between conservation and timber extraction priorities. In both Canada and the U.S., there are procedures for protecting the murrelet's nesting habitat, but it is critically important that the protected areas meet the murrelet's nesting habitat requirements and do not have unusually high densities of predators. Our study therefore focused on the adequacy of shoreline strip forests as reserves for murrelets. Conservation efforts adequately addressing the murrelet's complex and spacious habitat requirements usually benefit other oldgrowth associated species.

\section{METHODS}

Our study area on southwestern Vancouver Island, British Columbia, included large tracts of coniferous old-growth forest which support one of the largest populations of Marbled Murrelets south of Alaska (Burger 1995). Coastal observation stations were paired, with one station $20 \mathrm{~m}$ and another $250 \mathrm{~m}$ from the shoreline forest edge, and each pair spaced at least $0.5 \mathrm{~km}$ apart along the coast. Two observers sampled murrelet activities at each pair of stations on the same morning. Interior stations were selected to represent a range of habitat types and distances from the coast. In 1998 we compared 14 coastal stations (7 pairs) with 14 interior stations (7-21 km inland) in the abutting Carmanah and Walbran watersheds. In 1999 we compared 16 coastal stations (8 pairs) with 16 interior stations (1.5$10 \mathrm{~km}$ inland) in the Klanawa watershed and the adjacent shoreline. Each of the 30 survey stations was sampled three times in a single season, at intervals $>14$ days, within the core of the breeding season (midMay through mid-July). To test for annual variations in detections, we repeated the three surveys at the 14 interior Carmanah-Walbran stations in 1999.

To determine the presence and relative densities of Marbled Murrelets in forests, we followed the Pacific Seabird Group Inland Protocol (Ralph et al. 1994), modified for British Columbia (RIC 1997). The number of visual and auditory detections (Paton 1995) of murrelets was recorded during 2-hr surveys spanning sunrise. Some detections of murrelets (e.g., subcanopy and circling flights) were classified as "occupied behaviors" associated with nesting and near-nest behav- 
ior (Paton 1995). Detections were recorded by trained and experienced observers using tape recorders, transcribed on to standard data sheets and later to spreadsheets. We also recorded the occurrence and numbers of potential predators (crows, ravens, jays, owls, eagles, falcons, accipiters, and squirrels; Nelson 1997) during the dawn surveys. We set no limits on the distance for detecting predators, but most were within 100 $\mathrm{m}$; we did not use taped calls to attract them.

As an additional measure of murrelet activity, we calculated the ratio of occupied detections to all visual detections. This ratio is meant to identify stations with a high amount of occupied activity independent of the total visible activity observed, which is sometimes higher in flight corridors (Rodway and Regehr 1999). The ratio also compensates for differences in canopy openings at observation stations, which might affect the visibility and likelihood of detecting occupied behaviors. The obstruction of the visual field at observation stations was estimated in categories from 1-4 which corresponded to a projected canopy cover of 0 $25 \%, 26-50 \%, 51-75 \%$, and $76-100 \%$, respectively.

We recorded habitat measures relevant to murrelet nesting in $30 \times 30-\mathrm{m}$ plots in the forest stand nearest each survey station, following the standard protocol in British Columbia (RIC 1997). Within each plot we recorded the species, diameter at breast height (dbh), and height of all trees larger than $10 \mathrm{~cm}$ dbh, and the number of snags $>5 \mathrm{~m}$ tall. Tree heights were visually estimated after using a clinometer to establish the heights of 2-4 representative trees. Canopy closure (\% projected canopy cover) was estimated at 4-6 random locations within the plot, then averaged. Within each tree, we recorded features important for nesting by murrelets (Hamer and Nelson 1995), including: the number of potential nest platforms (limbs $>15 \mathrm{~m}$ above ground and $>18 \mathrm{~cm}$ in diameter, without making judgements about suitability as nest sites); estimated epiphyte cover $(0=$ none; $1=$ trace; $2=1-$ $33 \%$ cover; $3=34-66 \% ; 4=67-100 \%$ ), epiphyte thickness $(1=$ sparse, $2=$ intermediate, and $3=$ thick mats), and mistletoe infestation (Hawksworth 1977). In this last parameter, the live crown was divided into vertical thirds, and, for each third, mistletoe was scored as: $0=$ no visible infections, $1=$ light infections (half or less of branches infected), or $2=$ heavy infections (more than half infected). The total score was then added to give a range of scores from 0 to 6 and averaged for the whole plot.

STATISTICAL ANALYSES

Data were analyzed with SPSS 9.0. Variables not normally distributed were log-transformed, or if transformation failed to produce normality, were analyzed with nonparametric tests. To compare coastal with interior stations we used Student's $t$-tests (normal and transformed data) or Mann-Whitney tests (non-normal data untransformed). We used separate variances $t$-tests whenever Levene's test for equality of variances had a $P<0.05$. To compare the paired coastal stations (20 $\mathrm{m}$ and $250 \mathrm{~m}$ ), where each pair was sampled on the same day, we used paired $t$-tests (normal or transformed data) or Wilcoxon signed rank tests (non-normal data). All tests were two-tailed. We tested correlations between variables at interior stations and dis- tance from the ocean using Pearson correlation $(r)$ for normally distributed data and Spearman rank correlation $\left(r_{\mathrm{s}}\right)$ for non-normal data. Means are given $\pm \mathrm{SD}$. The level of statistical significance was $P<0.05$.

\section{RESULTS}

\section{COASTAL AND INTERIOR SITES COMPARED}

At 14 interior stations in Carmanah-Walbran sampled three times in each year, we found no significant differences between years for total detections per survey (mean 1998: $21.1 \pm$ 8.9, 1999: $20.6 \pm$ 8.6; paired $t$ test, $\left.t_{13}=0.17, P>0.50\right)$, occupied detections per survey (mean 1998: $2.6 \pm 2.5,1999: 4.4 \pm 3.8 ; t_{13}=$ $1.62, P>0.10)$, and subcanopy detections per survey (mean 1998: $2.0 \pm 2.1,1999: 3.2 \pm 3.0 ; t_{13}=1.20, P$ $>0.20)$. We assumed similar lack of annual variation at other stations and pooled data from both years. Our sample was thus 30 coastal and 30 interior stations, each sampled three times in a single year. Five surveys were missed due to inclement weather and so we had a total of 88 surveys at the coast and 87 in the interior.

Detections of Marbled Murrelets per survey were higher at interior than coastal stations (Table 1). Of greatest relevance was the difference in occupied and subcanopy detections, as indicators of likely nesting activity, which were both more than five times higher in the interior than at the coast. All 87 surveys in the interior recorded murrelet detections, $49 \%$ recorded occupied detections, and $43 \%$ recorded subcanopy detections compared to $85 \%, 19 \%$, and $16 \%$, respectively in the 88 coastal surveys.

The mean canopy closure at observation stations was higher at the coast than in the interior (Table 1), which might have affected visibility and hence detection rates. We tested the effects of visibility two ways. First, using an ANOVA with canopy closure as a covariate, significant differences persisted between interior and coastal stations in total $\left(F_{1.57}=25.1, P<\right.$ $0.001)$, occupied $\left(F_{1,57}=8.7, P=0.001\right)$, and subcanopy detections $\left(F_{1,57}=7.8, P=0.001\right)$. The variables violated assumptions used in ANOVA (they were not normally distributed and had unequal variances), but when sample sizes in groups are equal the ANOVA is robust despite these violations (Zar 1996). Second, we controlled visibility by considering the ratio of occupied to all visible detections. The differences between the interior and coast persisted (Table 1), indicating that they were not just an artifact of visibility.

Predator densities were three times higher at the coast than at interior stations (Table 1). Predators were reported in $88 \%$ of the coastal surveys but only $58 \%$ of the interior surveys. These results were mainly due to the high numbers of Northwestern Crows (Corvus caurinus) and Bald Eagles (Haliaeetus leucocephalus) at the coast. Both are primarily shoreline scavengers and seldom venture far inland, although both were seen at interior stations on rare occasions.

The comparison of vegetation attributes between coastal and interior stations yielded varying results (Table 1). We found no significant difference between the interior and coast in the mean height or diameter of trees, or tree density, but there was a higher density of larger trees $(>80 \mathrm{~cm} \mathrm{dbh})$ at interior stations, which contributed to a higher mean basal area in the interior. 
SHORT COMMUNICATIONS

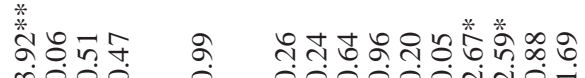
molo

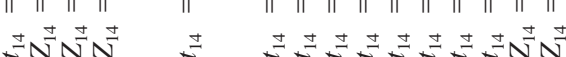

tas

\| \| $\|$ \|

oponiso

$\stackrel{ \pm}{N} N^{ \pm} N^{ \pm}$

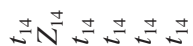

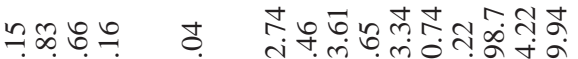

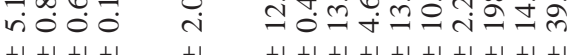

$\infty \cdot \div \cdot=$

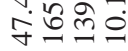

$+1+1+1+1+1+1+1+1+1+1$

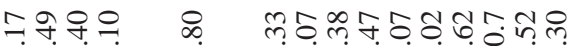

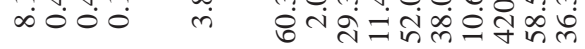

$+1+1+1$

किं

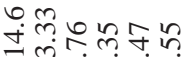

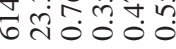

$+1+1+1+1+1+1$

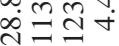

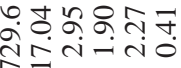

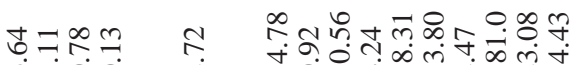

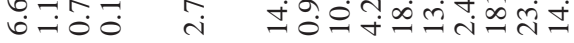

$+1+1+1+1 \quad+1 \quad+1+1+1+1+1+1+1+1+1+1$

규ำ 유

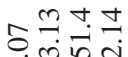

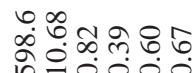

$+1+1+1+1+1+1$

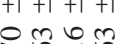

miga

ำ

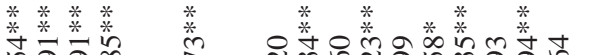

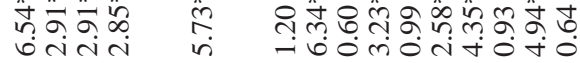

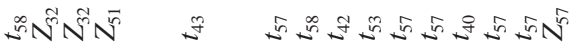

*

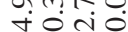

|| || || $\mid$

กิำ

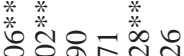

inंom-

|| || || || || ||

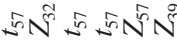

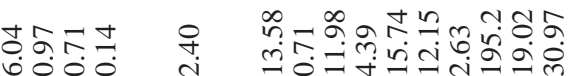

$\begin{array}{lll}0,1+1+1 & +1 & +1+1+1+1+1+1+1+1+1+1\end{array}$

țํำ?

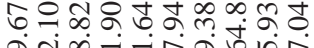

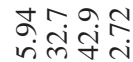

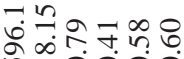

$+1+1+1+1$

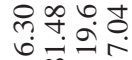

$+1+1+1+1+1+1$

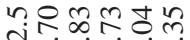

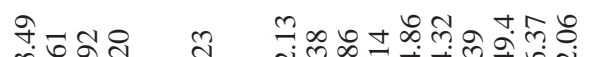

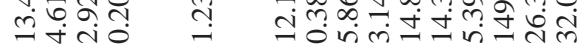

$+1+1+1+1 \quad+1 \quad+1+1+1+1+1+1+1+1+1+1$

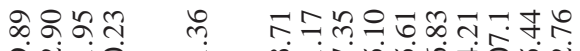

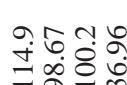

Nin- no

शेंत-

बु-

$+1+1+1+1$

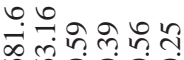

+2 ?

$+1+1+1+1+1+1$

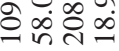

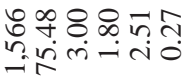

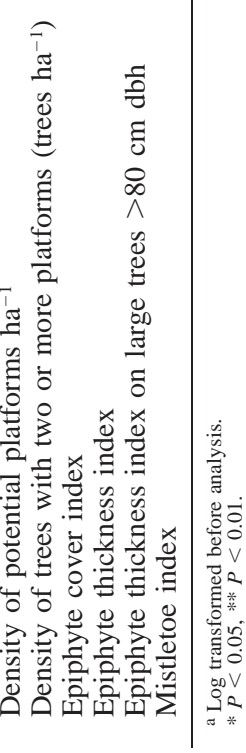


The size of trees and the shape of the canopy were more variable in the interior, as indicated by significant differences in the SDs of tree height and dbh. Species composition varied somewhat between the coast and interior: we found higher densities of western hemlock (Tsuga heterophylla) and amabilis fir (Abies amabilis) in the interior than at the coast, but no differences in densities of Sitka spruce (Picea sitchensis) or western red-cedar (Thuja plicata).

The canopy microhabitat provided more potential nest sites in the interior than at the coast: both the density of potential platforms per hectare, and the density of trees with two or more potential platforms were higher inland (Table 1). Most of the measures of epiphyte cover were similar in both areas, but mean epiphyte thickness on large trees, in which murrelets would most likely nest, was higher in the interior than at the coast. Mistletoe sometimes created platforms suitable for nesting by murrelets but was relatively rare, restricted to hemlock trees, and found in similar amounts in both areas (Table 1).

\section{COMPARISON AMONG COASTAL STATIONS}

The mean frequency of all murrelet detections (log transformed) was significantly higher at the $250-\mathrm{m}$ than at the 20-m stations, but occupied and subcanopy detections, and the ratio of occupied to all visual detections did not differ significantly (Table 1). Densities of predators were similar at both sets of stations. Crows and eagles were regularly seen roosting and moving about in the canopy at the $250-\mathrm{m}$ stations, indicating high risk to murrelets nesting there. In general there were few significant differences in habitat measures between the two sets of stations, although tree density and basal area were lower at 20-m than 250 $\mathrm{m}$ stations, and Sitka spruce was more common at 20$\mathrm{m}$ than 250-m. Epiphyte thickness scored slightly lower at $20-\mathrm{m}$ than $250-\mathrm{m}$, probably as a result of inhibition by salt spray. Other measures of canopy microhabitat were similar at the two distances, and both had similar densities of potential platforms and trees with two or more potential platforms.

\section{EFFECT OF DISTANCE FROM SEA AT INTERIOR STATIONS}

Among the 30 interior stations we found no significant correlations with increasing distance from the sea for any of the murrelet activity measures or most of the habitat variables. Significant positive correlations with distance from sea were found for snag density $\left(r_{\mathrm{s}}=\right.$ $0.73, n=30, P<0.001)$ and density of trees with two or more platforms $\left(r_{\mathrm{s}}=0.56, n=30, P<0.01\right)$. Negative correlations were found for predator densities $(r=-0.52, n=30, P<0.01)$ and mistletoe score $\left(r_{\mathrm{s}}\right.$ $=-0.38, n=30, P<0.05)$. With increasing distance from the sea the density of western red-cedar declined $\left(r_{\mathrm{s}}=-0.54, n=30, P<0.01\right)$, but amabilis fir increased $\left(r_{\mathrm{s}}=0.46, n=30, P<0.05\right)$, and Sitka spruce and western hemlock were unaffected.

\section{DISCUSSION}

With data from two years and three watersheds we found that near-nest flight activity (occupied and subcanopy detections) of Marbled Murrelets was significantly less within $250 \mathrm{~m}$ of the coast than at interior stations. Although the exact relationship between detection frequencies and nest density is unknown (Paton 1995), these results suggest a significantly lower use of the coastal fringe for nesting than in the interior forests. Elsewhere on Vancouver Island, in Clayoquot Sound, Rodway and Regehr (1999) found significantly fewer occupied detections near ocean edges than farther inland. In Washington, Hamer (1995) observed no evidence of occupancy by murrelets within $800 \mathrm{~m}$ of the coast even though the vegetation characteristics indicated excellent habitat. Few nests have been found within $1 \mathrm{~km}$ of the ocean, except in parts of Alaska where there is frequently no suitable interior forest (Hamer and Nelson 1995, Manley 1999).

The low level of occupied behavior on the coast was partly due to habitat effects. We found significantly fewer of the microhabitat canopy features important to murrelets for nesting (Hamer and Nelson 1995, Nelson 1997, Manley 1999) at the coastal stations: fewer potential nest platforms, fewer trees with platforms, thinner epiphyte mats on the boughs of large trees, and less structural diversity in the canopy. A structurally diverse canopy improves access by murrelets to limbs suitable for nesting. Severe winter storms and yearround salt spray on the open Pacific coast undoubtedly inhibited epiphyte growth, blew off thick moss mats, pruned off dead limbs likely to provide platforms, and created a more uniform canopy surface. Foliage above nest platforms, providing protection from weather and reducing visibility to predators (Hamer and Nelson 1995, Nelson 1997, Manley 1999), appeared less common over platform limbs at the coast than in the interior, but we were not able to quantify this. At exposed coasts on the Queen Charlotte Islands, Rodway et al. (1991) found fewer murrelets and less suitable nesting habitat than farther inland, which they attributed to salt spray inhibiting moss growth.

A second factor associated with low murrelet activity near the coast was the high density of predators there, particularly Bald Eagles and Northwestern Crows. Both of these species are primarily shoreline scavengers and predators of marine organisms, but are likely to prey on murrelets if encountered in the forest canopy. Bald Eagles are effective predators of adult alcids at colonies (DeGrange and Nelson 1992), including those in forests (Kaiser 1989). Northwestern Crows are extremely opportunistic, and known to take eggs and chicks from alcids and forest nesting birds (Verbeek and Butler 1999). Other common nest predators, such as Steller's Jays (Cyanocitta stelleri), Common Ravens (Corvus corax), and red squirrels (Tamiasciurus hudsonicus) were no more common at the coast than in the interior (A. E. Burger, unpubl. data). Predators are the main cause of failure for breeding Marbled Murrelets, and were responsible for failure of $43 \%$ of 32 nests across the Pacific Northwest (Nelson and Hamer 1995), and 66\% of 21 nests in British Columbia (Manley 1999). Rodway and Regehr (1999) observed high frequencies of predators at ocean edges in Clayoquot Sound, and Hamer (1995) speculated that high predator densities contributed to the lack of occupied behavior by murrelets along the Washington coast.

Marbled Murrelets are known to nest in most of the 
large coniferous tree species (Nelson 1997). In our study area, Sitka spruce and western hemlock provided more potential nest sites than western red-cedar and amabilis fir (unpubl. data). We found higher densities of western hemlock and amabilis fir in the interior than at the coast, but no differences in densities of Sitka spruce or western red-cedar. Species composition therefore did not appear to be an important factor in murrelet habitat suitability.

Within the coastal strip, the occurrence and frequencies of occupied and subcanopy behaviors by murrelets, predator densities, and most habitat features were similar at the stations $20 \mathrm{~m}$ and $250 \mathrm{~m}$ from the forest edge. Epiphyte cover was thinner at the 20-m stations, but other microhabitat features were similar. The deleterious effects of the exposed shore and the high densities of eagles and crows extended at least $250 \mathrm{~m}$ inland. Among the 30 interior stations there was a significant increase in density of trees with two or more platforms, and a decrease in predator density, with increasing distance from the sea, suggesting that these might have been clinal effects not entirely restricted to the 250-m wide coastal strip. Murrelet detections and most other critical nest habitat features showed no correlation with distance from the sea within the interior stations, suggesting that those coastal effects did not extend beyond $1.5 \mathrm{~km}$ inland. Unfortunately, lack of roads or hiking trails made it impossible to sample habitats from $250 \mathrm{~m}$ to $1.5 \mathrm{~km}$ inland, so we could not test how far inland all the shoreline effects extended.

The differences between coastal and interior stations were not due to habitat fragmentation or artificial edgeeffects caused by logging or road-building. All the stations, except some in the interior Klanawa Valley, were in continuous large tracts of forests $(>1,000 \mathrm{ha})$ and not in isolated stands. The interior forests were therefore more suitable for murrelets, despite some fragmentation and loss of habitat.

Our coastal stations were all within Pacific Rim National Park. Much of this park is a narrow coastal strip less than $1 \mathrm{~km}$ wide. Elsewhere on Vancouver Island (e.g., Clayoquot Sound), the Olympic Peninsula in Washington, and in other parts of the Pacific Northwest, similar coastal strips have been protected. These strips are included in the protected habitat considered to be available for Marbled Murrelets, but our data suggest that these shoreline strips are unlikely to support viable populations of Marbled Murrelets. Furthermore, future protection of habitat, such as the implementation of the British Columbia Forest Practices Code, should consider coastal strips as suboptimal habitat. Our research shows that the shoreline effects extend at least $250-\mathrm{m}$ inland, and further research is needed to establish the limits of these effects wherever murrelets might be nesting. As an interim measure, we suggest placing protected areas for murrelets $>1 \mathrm{~km}$ inland.

Our research was funded by Forest Renewal British Columbia (Research), Endangered Species Recovery Fund (World Wildlife Fund Canada and Environment Canada), Habitat Conservation Trust Fund of British Columbia, and Friends of Ecological Reserves. Logistical support and permits were provided by Pacific Rim National Park (Heritage Canada) and Carmanah-Wal- bran Provincial Park (B.C. Parks), and we thank the wardens of both parks, and particularly Bob Redhead, for continued support. We thank the Etzkorn family at Carmanah Light Station for help and hospitality, Carl Edgar Jr. for boat transportation, and Kathy Kuletz, Andrea Lawrence, and Kim Nelson for helpful comments on the paper. Most importantly, we thank our fellow field workers (Kendra Clare, Chris Darimont, Jennifer Grant, Deanna Newsom, and Anna Young) for their excellent work and companionship. This paper is dedicated to the memory of Kelsey Lawrence-Burger whose spirit remains in these forests.

\section{LITERATURE CITED}

Burger, A. E. 1995. Marine distribution, abundance, and habitats of Marbled Murrelets in British Columbia, p. 295-312. In C. J. Ralph, G. L. Hunt Jr., M. G. Raphael, and J. F. Piatt [EDS.], Ecology and conservation of the Marbled Murrelet. Gen. Tech. Rep. PSW-GTR-152, Pacific Southwest Res. Sta., Forest Serv., U.S. Dept. Agriculture, Albany, CA

DeGrange, A. R., And J. W. Nelson. 1982. Bald Eagle predation on nocturnal seabirds. J. Field Ornithol. 53:407-409.

HAMER, T. E. 1995. Inland habitat associations of Marbled Murrelets in western Washington, p. 163175. In C. J. Ralph, G. L. Hunt Jr., M. G. Raphael, and J. F. Piatt [EDS.], Ecology and conservation of the Marbled Murrelet. Gen. Tech. Rep. PSWGTR-152, Pacific Southwest Res. Sta., Forest Serv., U.S. Dept. Agriculture, Albany, CA.

Hamer, T. E., AND S. K. Nelson. 1995. Characteristics of Marbled Murrelet nest trees and nesting stands, p. 69-82. In C. J. Ralph, G. L. Hunt Jr., M. G. Raphael, and J. F. Piatt [EDS.], Ecology and conservation of the Marbled Murrelet. Gen. Tech. Rep. PSW-GTR-152, Pacific Southwest Res. Sta., Forest Serv., U.S. Dept. Agriculture, Albany, CA.

HawksworTH, F. G. 1977. The 6-class dwarf mistletoe rating system. Gen. Tech. Rep. RM-48. Rocky Mountain Res. Sta., Forest Service, U.S. Dept. Agriculture, Fort Collins, CO.

KAISER, G. W. 1989. Nightly concentration of Bald Eagles at an auklet colony. Northwestern Naturalist 70:12-13.

Manley, I. A. 1999. Behaviour and habitat selection of Marbled Murrelets nesting on the Sunshine Coast. M.Sc. thesis, Simon Fraser Univ., Burnaby, B.C., Canada.

Nelson, S. K. 1997. Marbled Murrelet (Brachyramphus marmoratus). In A. Poole and F. Gill [EDS.], The birds of North America, No. 276. The Academy of Natural Sciences, Philadelphia, and The American Ornithologists' Union, Washington, DC.

Nelson, S. K., and T. E. Hamer. 1995. Nest success and the effects of predation on Marbled Murrelets, p. 89-97. In C. J. Ralph, G. L. Hunt Jr., M. G. Raphael, and J. F. Piatt [EDS.], Ecology and conservation of the Marbled Murrelet. Gen. Tech. Rep. PSW-GTR-152, Pacific Southwest Res. Sta., Forest Serv., U.S. Dept. Agriculture, Albany, CA.

Paton, P. W. C. 1995. Marbled Murrelet inland patterns of activity: defining detections and behavior, p. 113-116. In C. J. Ralph, G. L. Hunt Jr., M. G. Raphael, and J. F. Piatt [EDS.], Ecology and con- 
servation of the Marbled Murrelet. Gen. Tech. Rep. PSW-GTR-152, Pacific Southwest Res. Sta., Forest Serv., U.S. Dept. Agriculture, Albany, CA. Ralph, C. J., G. L. Hunt JR., M. G. Raphael, AND J. F. PIATT. 1995. Overview of the ecology and conservation of the Marbled Murrelet in North America, p. 3-22. In C. J. Ralph, G. L. Hunt Jr., M. G. Raphael, and J. F. Piatt [EDS.], Ecology and conservation of the Marbled Murrelet. Gen. Tech. Rep. PSW-GTR-152, Pacific Southwest Res. Sta., Forest Serv., U.S. Dept. Agriculture, Albany, CA.

Ralph, C. J., S. K. Nelson, M. M. Shaughnessy, S. L. Miller, AND T. E. Hamer. 1994. Methods for surveying Marbled Murrelets in forests. Pacific Seabird Group, Marbled Murrelet Technical Committee, Tech. Paper No. 1. Oregon Co-operative Wildl. Res. Unit, Oregon State Univ., Corvallis, OR.

RIC (Resources Inventory Committee). 1997. Standardized inventory methodologies for components of British Columbia's biodiversity: Marbled Murrelets in marine and terrestrial habitats. Version 1.1. Publication No. 208, B.C. Resources Inven- tory Committee, Ministry of Environment, Lands and Parks, Victoria, B.C., Canada.

RodWAY, M. S., AND H. M. REGEHR. 1999. Inland inventory: Marbled Murrelet activity and structural characteristics of old-growth forests in Clayoquot Sound, British Columbia, 1995-1997, p. 119-236. In T. A. Chatwin, A. E. Burger, and L. E. Jones [EDS.], Inventory of Marbled Murrelets in Clayoquot Sound, 1997. Unpublished report to B.C. Ministry of Environment, Lands and Parks, Vancouver Island Regional Office, Nanaimo, B.C., Canada.

Rodway, M. S., J.-P. L. SAVArd, AND H. M. Regehr 1991. Habitat use and activity patterns of Marbled Murrelets at inland and at-sea sites in the Queen Charlotte Islands, British Columbia. Tech. Rep. Ser. No. 122. Canadian Wildlife Service, Pacific and Yukon Region, Delta, B.C., Canada.

VerbeEK, N. A. M., aND R. W. ButLer. 1999. Northwestern Crow (Corvus caurinus). In A. Poole and F. Gill [EDS.], The birds of North America, No. 407. Birds of North America, Inc., Philadelphia.

Zar, J. H. 1996. Biostatistical analysis. 3rd ed. Prentice Hall, Upper Saddle River, NJ.

\title{
CORRELATES OF HARLEQUIN DUCK DENSITIES DURING WINTER IN PRINCE WILLIAM SOUND, ALASKA ${ }^{1}$
}

\author{
DANIEL ESLER \\ U.S. Geological Survey, Alaska Biological Science Center, 1011 E. Tudor Rd., Anchorage, AK 99503, \\ e-mail: daniel_esler@usgs.gov \\ TiмOTHY D. BOWMAN \\ U.S. Fish and Wildlife Service, 1011 E. Tudor Rd., Anchorage, AK 99503 \\ THOMAS A. DEAN \\ Coastal Resources Associates, Inc., 1185 Park Center Dr., Suite A, Vista, CA 92083 \\ Charles E. O'Clair \\ National Oceanographic and Atmospheric Administration, Auke Bay Laboratory, 11305 Glacier Highway, \\ Juneau, AK 99801 \\ STEPHEN C. JEWETT \\ Institute of Marine Science, University of Alaska Fairbanks, Fairbanks, AK 99775 \\ LYMAN L. MCDONALD \\ Western Ecosystems Technology, Inc., 2003 Central Ave., Cheyenne, WY 82001
}

Abstract. We evaluated relationships of Harlequin Duck (Histrionicus histrionicus) densities to habitat attributes, history of habitat contamination by the 1989

\footnotetext{
${ }^{1}$ Received 15 February 2000. Accepted 25 July 2000.
}

Exxon Valdez oil spill, and prey biomass density and abundance during winters 1995-1997 in Prince William Sound, Alaska. Habitat features that explained variation in duck densities included distance to streams and reefs, degree of exposure to wind and wave action, and dominant substrate type. After accounting for 
these effects, densities were lower in oiled than unoiled areas, suggesting that population recovery from the oil spill was not complete, due either to lack of recovery from initial oil spill effects or continuing deleterious effects. Prey biomass density and abundance were not strongly related to duck densities after accounting for habitat and area effects. Traits of Harlequin Ducks that reflect their affiliation with naturally predictable winter habitats, such as strong site fidelity and intolerance of increased energy costs, may make their populations particularly vulnerable to chronic oil spill effects and slow to recover from population reductions, which may explain lower densities than expected on oiled areas nearly a decade following the oil spill.

Key words: density, Exxon Valdez oil spill, food, habitat, Harlequin Duck, Histrionicus histrionicus, population recovery.

Harlequin Ducks (Histrionicus histrionicus) are inextricably linked to nearshore marine environments during the nonbreeding portion of the annual cycle throughout their holarctic range. Adults leave coastal areas only for a few summer months when they migrate to fast-moving streams to nest and raise broods Despite the importance of nearshore areas for Harlequin Duck populations, fine-scale winter habitat associations rarely have been quantified.

In March 1989, the Exxon Valdez ran aground, spilling nearly 42 million liters of oil into Prince William Sound, a wintering area for approximately 14,000 Harlequin Ducks. As much as $40 \%$ of the spilled oil was deposited in intertidal and shallow subtidal zones of Prince William Sound (Wolfe et al. 1994), the areas used by Harlequin Ducks. Although much of the oil degraded and dissipated within a few years of the spill, some residual oil was still present in these areas through at least 1997 (Hayes and Michel 1999). Immediate bird mortality from the Exxon Valdez oil spil was high (Piatt et al. 1990) and more than 1,000 Harlequin Ducks were estimated to have died as an immediate and direct result of the spill (J. Piatt, U.S Geological Survey, pers. comm.). Furthermore, there have been concerns about continued effects of the Exxon Valdez oil spill on Harlequin Duck populations and lack of full population recovery (Esler et al. 2000)

We studied Harlequin Duck habitat associations in Prince William Sound during winter to identify environmental variables that relate to Harlequin Duck densities and to assess the status of Harlequin Duck populations following the Exxon Valdez oil spill. Evaluation of Harlequin Duck population recovery from the oil spill has been constrained by a paucity of prespill data from winter, the season of highest abundance of Harlequin Ducks in Prince William Sound and likely the period of formation of core subpopulations from a population structure perspective (Cooke et al. 2000) For this study, we adopted a control-impact study design to assess potential oil spill effects, in which we compared densities of Harlequin Ducks between oiled and unoiled areas, recognizing the need to control for intrinsic area differences (Wiens and Parker 1995).

Lower densities than expected on oiled areas (after accounting for other environmental factors) could result from either failure to recover from immediate population impacts or from continuing deleterious effects of the spill; either case would lead to an interpretation of lack of full population recovery.

\section{METHODS}

\section{STUDY AREA}

Study locations were within oiled and unoiled areas of Prince William Sound, Alaska. The oiled study area included $75.7 \mathrm{~km}$ of shoreline within two bays on Knight Island, Herring Bay and Bay of Isles, which were heavily oiled by the Exxon Valdez spill. The unoiled area was $74.1 \mathrm{~km}$ of shoreline in the Stockdale Harbor and Port Chalmers region of northwestern Montague Island, selected because of the close proximity to the oil spill zone.

Analyses of habitat associations were based on measurement of habitat attributes and Harlequin Duck densities at sampling sites within each study area. To select sites, the shoreline of each study area was divided into contiguous $200-\mathrm{m}$ sections. From randomly selected start points, 216 sections (113 on Knight Island and 103 on Montague Island) were then systematically selected as sampling sites, resulting in coverage throughout each study area.

\section{HARLEQUIN DUCK SURVEYS}

We surveyed Harlequin Duck numbers and distribution during 4-12 December 1995, 12-24 February 1996, 4-14 December 1996, and 14-23 February 1997, completing five replicates on Knight Island and seven on Montague Island. Surveys were conducted by boat with a two- or three-person team consisting of an operator/observer and at least one observer/data recorder. For all Harlequin Ducks observed within $200 \mathrm{~m}$ of the study area shoreline, we recorded flock sizes and mapped locations on mylar overlays of 1:15,000 aerial photos.

To estimate Harlequin Duck densities associated with each sampling site, we calculated the number of ducks detected during shoreline censuses within 200$\mathrm{m}$ linear shoreline distance of the midpoint of each sampling site. Duck densities were expressed as the average number of birds associated with the sampling site over all replicate surveys. Harlequin Duck numbers were consistent across surveys $(\mathrm{CV}=4.1 \%$ on Montague Island and $8.0 \%$ on Knight Island) and Harlequin Duck site fidelity is high (Robertson et al. 1999, Cooke et al. 2000), suggesting that average densities should be a robust indicator of Harlequin Duck use of each site. Replication and duration of surveys resulted in data collection over a range of tidal states and weather conditions in both areas, and thus any variation potentially related to these factors should not influence inter-area comparisons.

\section{HABITAT ATTRIBUTES}

At each site, we measured several habitat variables, including: exposure-a description of wind and wave action, categorized as full exposure, partial exposure, and not exposed; dominant substrate-categorized as rocky (bedrock and boulder areas) and mixed (unconsolidated, i.e., various mixtures of sand, pebbles, and cobble); distance to stream mouth—straight line dis- 
tance from the midpoint of the sampling site to nearest stream mouth categorized as $<200 \mathrm{~m}, 200-500 \mathrm{~m}$, $>500-1,000 \mathrm{~m}$, and $>1,000 \mathrm{~m}$; distance to reefstraight line distance from the midpoint of the sampling site to the nearest offshore reef (defined as covered at high tide but exposed at lower tides) categorized as $200-500 \mathrm{~m},>500-1,000 \mathrm{~m}$, and $>1,000 \mathrm{~m}$; and intertidal slope - the average slope (in degrees) of the mussel zone. Observations with missing data for a habitat variable were excluded from habitat association models that included that variable.

\section{HABITAT ASSOCIATION MODELS}

We conducted general linear model analyses to assess relationships of habitat attributes (explanatory variables) to average Harlequin Duck densities (the response variable), using each sampling site as an observation. Scatterplots of Harlequin Duck densities by habitat and food variables indicated that distributions violated the assumption of linearity; square-root transformation of Harlequin Duck densities resolved this problem. Categorical variables were included as a set of indicator variables, with one level of each variable designated as the reference level and, thus, not included in model selection procedures (Ramsey and Schafer 1997).

To select the model from which we drew inference, we used Mallow's $C_{p}$ values to contrast all possible combinations of explanatory variables. Explanatory variables included all habitat parameters, their interactions with area, and an area (oiling history) term. This method of model selection uses the principle of parsimony to determine which model is best fit by the data (Burnham and Anderson 1998), avoiding assumptions and biases of traditional stepping (i.e., forward, backward, and stepwise) model selection procedures (Flack and Chang 1987). Using this approach to model selection, the model with the lowest $C_{p}$ value is the one best supported by the data and, thus, provides the strongest inference. We interpreted inclusion of a given parameter in a selected model as evidence that the parameter was related to Harlequin Duck densities, after accounting for effects of other included parameters Inclusion of the area term in the best-fitting model would suggest that oiling history was related to Harlequin Duck densities after accounting for any effects of habitat attributes and differences in effects of habitat attributes between areas.

\section{THE ROLE OF FOOD}

Harlequin Ducks in marine areas eat intertidal and shallow subtidal benthic invertebrates, particularly amphipods, limpets, snails, chitons, and mussels (Goudie and Ankney 1986). We sampled Harlequin Duck prey in each area at a systematically selected subset of 15 of the sampling sites. Because of generally low densities of Harlequin Ducks on Knight Island, four additional sites with relatively higher Harlequin Duck densities were selected to ensure that sampling represented the full range of Harlequin Duck densities. Similarly, four sites with moderate to low duck densities were added on Montague Island.

To sample intertidal blue mussels (Mytilus trossu$l u s$ ), we removed all mussels from within $10500-\mathrm{cm}^{2}$ quadrats placed in the mussel zone of each site. Ash- free dry mass of each mussel 5-25 mm in length was estimated based on predictive equations of biomass by length (Holland-Bartels 2000). Samples of other invertebrate prey (limpets, chitons, lacunid snails, littorine snails, other snails, amphipods, and other crustaceans) were obtained at six intertidal and shallow subtidal locations within each prey sampling site. All epifauna were removed from a $0.25-\mathrm{m}^{2}$ quadrat at each location. Ash-free dry weights of each prey item $<25$ $\mathrm{mm}$ in length were determined using a muffle furnace.

For data analyses, prey data were included in four forms: total food biomass density-the combined average biomass densities ( $\mathrm{g}$ per $100 \mathrm{~m}^{2}$ ) of mussels and other prey items; total food abundance-an estimate of the biomass ( $\mathrm{kg}$ ash-free dry mass) of all food types within the 200-m sampling site, based on expansion of food biomass densities to the prey sampling areas; food biomass density without mussels-we also used biomass density estimates excluding mussels because biomass estimates of mussels were considerably higher (usually more than an order of magnitude) than other prey types, yet they constitute a relatively small part of the diet of Harlequin Ducks; and food abundance without mussels-similarly, we used prey abundance estimates excluding mussels.

To examine effects of prey on Harlequin Duck distributions, we assessed additional variation in duck densities related to food variables after accounting for habitat and area effects. We regressed residuals (observed Harlequin Duck densities-predicted densities) from the best-fitting habitat association model against the four measures of prey abundance and density.

\section{RESULTS}

Harlequin Duck densities were considerably higher at unoiled Montague Island ( $3.0 \pm 0.2$; average ducks per $400 \mathrm{~m}$ shoreline \pm SE) than at oiled Knight Island (0.6 \pm 0.1 . Some aspects of the habitat were distinctly different between Montague and Knight Islands, including intertidal slope $(5.8 \pm 0.4$ and $25.5 \pm 1.7 \mathrm{de}$ grees, respectively) and dominant substrate (37.9\% and $73.5 \%$ rocky, respectively). On both areas, Harlequin Ducks were almost always observed in intertidal and shallow subtidal habitats very close to shore.

\section{HABITAT ASSOCIATION MODELS}

In the best-fitting model (Table 1), Harlequin Duck densities were positively related with having an offshore reef within $500 \mathrm{~m}$, a stream within $200 \mathrm{~m}$, and full exposure. The main effect of mixed substrate also had a positive parameter estimate, although there was a larger negative interaction of area by mixed substrate, suggesting that Harlequin Duck densities were positively associated with mixed substrate on Montague Island and negatively associated on Knight Island (Table 1). The rest of the top five models (those with the next four lowest Mallow's $C_{p}$ values) also included the terms from the best-fitting model, indicating their importance for explaining variation in Harlequin Duck densities.

\section{EFFECTS OF HISTORY OF OIL CONTAMINATION}

The area term was included in the best-fitting model and had a large, negative parameter estimate (Table 1). In other words, duck densities were lower on oiled 
TABLE 1. Results of general linear model analyses to evaluate relationships of Harlequin Duck densities (square-root transformed) in Prince William Sound, Alaska, winters 1995-1997, with habitat attributes and history of oil contamination by the 1989 Exxon Valdez oil spill. The parameter estimates ( \pm SE) are from the best-fitting model, based on comparisons of all possible combinations of habitat attribute variables, habitat by area interactions, and an area (history of oil contamination) term.

\begin{tabular}{lllr}
\hline \hline Response variable & $R^{2}$ & Explanatory variable & Parameter estimate \\
\hline Ducks per $400 \mathrm{~m}$ & 0.45 & Intercept & $1.17 \pm 0.12$ \\
& Reef 200-500 $\mathrm{m}^{\mathrm{a}}$ & $0.51 \pm 0.15$ \\
& Stream 0-200 $\mathrm{m}^{\mathrm{a}}$ & $0.34 \pm 0.14$ \\
& Full exposure & $0.45 \pm 0.12$ \\
& Mixed substrate & $0.32 \pm 0.14$ \\
& Mixed substrate $\times$ Area $^{\mathrm{b}}$ & $-0.48 \pm 0.18$ \\
& Area & $-0.69 \pm 0.12$ \\
\hline
\end{tabular}

${ }^{a}$ Parameter estimate is in relation to all other levels of the categorical variable.

b Reference value for area is unoiled Montague Island; parameter estimates are interpreted as effects on oiled Knight Island.

Knight Island than unoiled Montague Island (the reference level for the area term) after accounting for effects of habitat attributes and differences in these attributes between areas, which we interpret as evidence that history of oil contamination was related to Harlequin Duck densities. All of the top five models included the area term. Also, a more complicated analysis of our data, in which the area term was added after selection of models including only habitat variables, found an exactly concordant result-oiling history was strongly and negatively related to Harlequin Duck densities (Holland-Bartels 2000).

\section{THE ROLE OF FOOD}

Duck density residuals were not related to total food abundance $\left(R^{2}<0.01, F_{1,30}=0.02, P=0.89\right)$, total food biomass density $\left(R^{2}<0.01, F_{1,31}=0.03, P=\right.$ $0.87)$, or food abundance without mussels $\left(R^{2}=0.04\right.$, $F_{1,36}=1.52, P=0.23$ ). Food biomass density without mussels was positively correlated with duck density residuals $\left(R^{2}=0.17, F_{1,37}=7.83, P=0.01\right)$. However, the amount of variation explained was low and the relationship was highly influenced by a single obser-

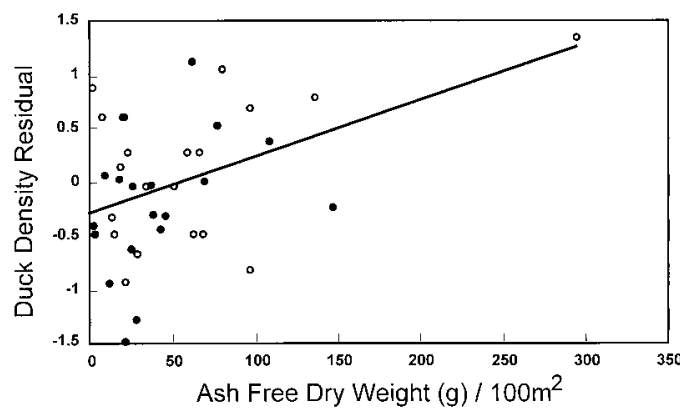

FIGURE 1. Linear relationship of residuals of Harlequin Duck densities (ducks/400 m shoreline; squareroot transformed) from a general linear model of habitat associations against prey biomass density. Empty circles represent Knight Island (oiled) study sites and solid circles represent Montague Island (unoiled) sites. vation (Fig. 1), a site on oiled Knight Island that was nonsystematically selected to represent high duck densities and which also had high densities of subtidal foods (especially snails and amphipods); without this observation, the relationship was nonsignificant $\left(R^{2}=\right.$ $\left.0.07, F_{136}=2.62, P=0.11\right)$. Taken together, these analyses suggest that variation in food explained little variation in duck densities beyond that explained by habitat attributes.

\section{DISCUSSION}

\section{HABITAT RELATIONS TO HARLEQUIN DUCK WINTER} DENSITIES

We assume that habitat associations of Harlequin Ducks that we observed were related to habitat profitability and reflected, to some degree, solutions to the optimization process of balancing benefits of habitats against detrimental aspects (Abrahams and Dill 1989, Guillemette et al. 1993). This balance is influenced by ecological characteristics of the species (Hilden 1965), which in the case of Harlequin Ducks include a life history requirement for high winter survival and high levels of winter philopatry.

Few other studies have quantified winter Harlequin Duck habitat associations. Goudie and Ankney (1988) documented that Harlequin Ducks were closer to shore and used reefs more than other sea duck species in Newfoundland. Harlequin Duck winter habitats have been qualitatively characterized and consistently described as being very close to shore and in a varied mix of substrates (Vermeer 1983), in agreement with our findings. We found strong positive relationships between Harlequin Duck densities and full exposure, occurrence of nearby streams, and occurrence of nearby reefs. Presence of a stream may influence prey distribution and provide fresh water to reduce osmotic stress for birds that ingest salts while feeding on marine invertebrates (Nyström and Pehrsson 1988). Reefs likely serve as safe resting sites and also offer intertidal foraging opportunities.

Harlequin Duck habitat use and life history are inextricably linked. Among ducks, Harlequin Ducks are relatively long-lived and have low and variable annual productivity (Goudie et al. 1994), a life history that 
requires high survival. High survival, in turn, depends on selection of stable and predictable habitats. On a broad scale, coastal habitats are thought to offer more stable wintering environments for waterfowl than inland sites (Diefenbach et al. 1988). Within coastal habitats, Harlequin Ducks occupy the productive intertidal and shallow subtidal zones. Goudie and Ankney (1986) described Harlequin Ducks as living near an energetic threshold as a result of their small body size and relatively harsh wintering environments. Consequently, Harlequin Ducks must forage nearly continuously during daylight hours of winter (Goudie and Ankney 1986). The habitat associations that we documented are consistent with this foraging strategy. Use of shallow water reduces dive and search times for more efficient foraging (Guillemette et al. 1993). Use of areas near streams and reefs may reduce energetic costs and time of transit between foraging areas and other resources (e.g., fresher water, roost sites). In summary, Harlequin Ducks must use habitats that predictably allow them to meet daily energy costs within their time-limited foraging regime, while minimizing risk of mortality in concordance with their life history requirement for high survival probabilities.

\section{EFFECTS OF HISTORY OF OIL CONTAMINATION}

We found that after accounting for effects of habitat attributes, history of oil contamination from the Exxon Valdez spill was related to Harlequin Duck densities, with densities lower on oiled Knight Island than would be predicted based on the habitat attributes that we measured. Our data were consistent with a hypothesis that Harlequin Duck populations were not fully recovered from the oil spill.

Evidence from other studies supports a hypothesis that Harlequin Duck populations experienced continued effects of the Exxon Valdez oil spill during the course of this study. Trust et al. (2000) concluded that Harlequin Ducks and the ecologically similar Barrow's Goldeneye (Bucephala islandica) continued to be exposed to oil through 1998, as indicated by higher induction of cytochrome P450 1A in oiled areas than unoiled areas. Also, Harlequin Duck adult female survival during winters 1995-1998 was lower on oiled areas than unoiled areas (Esler et al. 2000), and laboratory studies support logical links between reduced survival rates and oil exposure (Holmes et al. 1979). Because population dynamics of birds with life histories like Harlequin Ducks are particularly sensitive to variation in adult female survival (Goudie et al. 1994 Schmutz et al. 1997), lower survival on oiled areas may have led to population declines (Rosenberg and Petrula 1998) and hence lower densities on oiled areas than predicted, as found in this study. Harlequin Duck populations have relatively low intrinsic growth rates (Goudie et al. 1994), so full recovery (i.e., duck densities at levels predicted from intrinsic habitat attributes) likely will not occur until long after deleterious effects of the oil spill have ceased.

Day et al. (1997) studied habitat use by birds in Prince William Sound during the period immediately following the Exxon Valdez spill (1989-1991) and found no oil spill effects on Harlequin Ducks during winter. Why were our results different from those of Day et al. (1997)? First, because deleterious effects of the oil spill continued through the period of our study and until at least 1998 (Rosenberg and Petrula 1998, Esler et al. 2000, Trust et al. 2000), differences in Harlequin Duck abundance relative to oil contamination may have been more pronounced during our study than during the study of Day et al. (1997). Also, Day et al. (1997) used bays as sampling units and characterized habitats at the scale of the entire bay, presumably by necessity due to their broader study question to look at all marine birds over a wider geographic area. Our study demonstrated that Harlequin Ducks respond to much smaller scale variations in habitat attributes. Harlequin Ducks exhibit high fidelity to specific shoreline segments (Robertson et al. 1999, Cooke et al. 2000), therefore, we were able to account for differences in environmental attributes at the scale that Harlequin Ducks select habitats before testing for relationships to history of oil contamination, allowing for a finer scale and presumably more powerful test.

\section{THE ROLE OF FOOD}

Food may influence the distribution and abundance of some sea ducks (Nilsson 1972, Guillemette et al. 1993). In the context of the Exxon Valdez oil spill, strong relationships between Harlequin Duck densities and food would indicate food limitation as a possible mechanism for lack of population recovery. However, we found that food explained little variation in duck densities beyond habitat attributes and area effects.

Foraging characteristics of Harlequin Ducks suggest that they may be more time-limited than food-limited. Energetic requirements of this small-bodied sea duck necessitate nearly continuous feeding during daylight hours of winter and a generalist diet that includes many common benthic invertebrates (Goudie and Ankney 1986). This foraging strategy, particularly in association with high levels of winter site fidelity (see below), suggests that food may be predictably abundant, and the crux for Harlequin Ducks is to maximize energy intake during a short daily foraging period. Other authors (Nilsson 1972) have found that food exploitation by some wintering diving ducks was small relative to standing crop; we suggest that this is likely the case for Harlequin Ducks.

\section{SIGNIFICANCE OF PHILOPATRY}

A growing body of data suggests that Harlequin Ducks exhibit high philopatry throughout their annual cycle (Cooke et al. 2000, Robertson et al. 2000). Harlequin Duck winter habitat use is likely influenced by strong philopatry (Cooke et al. 2000), which reflects high stability of nearshore environments coupled with advantages of philopatry, including site familiarity and interannual pair reunion (Robertson and Cooke 1999, Smith et al. 2000).

From the perspective of oil spill recovery, high winter philopatry suggests that if residual oil spill damages exist, birds from oiled areas are vulnerable to chronic and cumulative spill effects as they return to those areas each year. Also, if dispersal and movements among areas are limited, recovery of groups of birds in oiled areas must occur largely through production and recruitment specific to that group and numbers are not bolstered through immigration. Lower densities than 
expected on oiled areas detected in this study may be a result of one or both of these processes.

These data were collected under studies supported by the Exxon Valdez Oil Spill Trustee Council. However, the findings and conclusions presented by the authors are their own and do not necessarily reflect the views or position of the Trustee Council. We thank Dean Rand, captain of $M / V$ Discovery, U.S. Forest Service, Copper River Delta Research Institute, and U.S. Geological Survey, Alaska Biological Science Center for logistical support. The following people participated in bird surveys: Rick Ballas, Jeb Benson, Katherine Brenner, Paul Cotter, Aaron Johnson, Danielle Mather, Jeffrey Mason, Julie Morse, April Nielson, Jennifer Pratt, Daniel Ruthrauff, Ted Spencer, Mike Stattleman, and Kim Trust. Field assistance for prey sampling included Christine Brodersen, Mary Drew, Daniel Fremgen, Patricia Harris, Max Hoberg, Dennis Jung, Erica Leder, Mandy Lindeberg, Bruce March, Anita Martin, Joshua Millstein, John Moreland, Jerry Phillips, Jeffrey Reglin, Michelle Sleeter, Justin Stekoll, Robert Thomas, and Noele Weemes. Lab analysis of invertebrate prey was conducted by Mary Drew, Max Hoberg, Mandy Lindeberg, David Love, Bruce March, Joshua Millstein, and Justin Stekoll. Dave Douglas and Danielle Mather helped summarize spatial data. We thank Shay Howlin for statistical review, and Fred Cooke, Dirk Derksen, and Jerry Hupp for review of the manuscript.

\section{LITERATURE CITED}

Abrahams, M. V., AND L. M. Dill. 1989. A determination of the energetic equivalence of the risk of predation. Ecology 70:999-1007.

BurnhaM, K. P., AND D. R. Anderson. 1998. Model selection and inference: a practical information theoretic approach. Springer-Verlag, New York.

Cooke, F., G. J. Robertson, C. M. Smith, R. I. GouDIE, AND W. S. BoYD. 2000. Survival, emigration, and winter population structure of Harlequin Ducks. Condor 102:137-144.

Day, R. H., S. M. Murphy, J. A. Wiens, G. D. HayWARD, E. J. HARNER, AND L. N. SMITH. 1997. Effects of the Exxon Valdez oil spill on habitat use by birds in Prince William Sound, Alaska. Ecol. Appl. 7:593-613.

Diefenbach, D. R., J. D. Nichols, and J. E. Hines. 1988. Distribution patterns during winter and fidelity to wintering areas of American Black Ducks. Can. J. Zool. 66:1506-1513.

Esler, D., J. A. Schmutz, R. L. Jarvis, And D. M. MulCAHY. 2000. Winter survival of adult female Harlequin Ducks in relation to history of contamination by the Exxon Valdez oil spill. J. Wildl. Manage. 64:839-847.

Flack, V. F., and P. C. Chang. 1987. Frequency of selecting noise variables in subset regression analysis: a simulation study. Am. Stat. 41:84-86.

Goudie, R. I., AND C. D. AnKNEY. 1986. Body size, activity budgets, and diets of sea ducks wintering in Newfoundland. Ecology 67:1475-1482.

Goudie, R. I., AND C. D. ANKNEY. 1988. Patterns of habitat use by sea ducks wintering in southeastern Newfoundland. Ornis. Scand. 19:249-256.

Goudie, R. I., S. Brault, B. Conant, A. V. Kondratyev, M. R. Petersen, ANd K. Vermeer. 1994. The status of sea ducks in the North Pacific rim: toward their conservation and management. Trans. N. Am. Wildl. Nat. Res. Conf. 59:27-49.

Guillemette, M., J. H. Himmelman, and C. Barette. 1993. Habitat selection by Common Eiders in winter and its interaction with flock size. Can. J. Zool. 71:1259-1266.

HAYES, M. O., AND J. Michel. 1999. Factors determining the long-term persistence of Exxon Valdez oil in gravel beaches. Marine Poll. Bull. 38:92-101.

Hilden, O. 1965. Habitat selection in birds-a review. Ann. Zool. Fenn. 2:53-75.

Holland-Bartels, L. E. [ED.]. 2000. Mechanisms of impact and potential recovery of nearshore vertebrate predators following the 1989 Exxon Valdez oil spill. Exxon Valdez Oil Spill Restoration Project Final Report (Restoration Project 99025), U.S. Geol. Surv., Alaska Biol. Sci. Center, Anchorage, AK.

Holmes, W. N., J. Gorsline, and J. Cronshaw. 1979. Effects of mild cold stress on the survival of seawater-adapted Mallard ducks (Anas platyrhynchos) maintained on food contaminated with petroleum. Environ. Res. 20:425-444.

NiLsson, L. 1972. Habitat selection, food choice, and feeding habits of diving ducks in coastal waters of south Sweden during the non-breeding season. Ornis Scand. 3:55-78.

Nyström, K. G. K., And O. Pehrsson. 1988. Salinity as a constraint affecting food and habitat choice of mussel-feeding diving ducks. Ibis 130:94-110.

Piatt, J. F., C. J. Lensink, W. Butler, M. Kendziorek, AND D. R. NYESWANDER. 1990. Immediate impact of the "Exxon Valdez" oil spill on marine birds. Auk 107:387-397.

Ramsey, F. L., AND D. W. Schafer. 1997. The statistical sleuth: a course in methods of data analysis. Wadsworth, Belmont, CA.

Robertson, G. J., AND F. COOKE. 1999. Winter philopatry in migratory waterfowl. Auk 116:20-34.

Robertson, G. J., F. COOKe, R. I. Goudie, AND W. S. BOYD. 1999. Within-year fidelity of Harlequin Ducks to a moulting and wintering area, p. 5360. In R. I. Goudie, M. R. Petersen, and G. J. Robertson [EDS.], Behaviour and ecology of sea ducks. Can. Wildl. Serv. Occ. Paper Series No. 100, Ottawa, Ontario, Canada.

Robertson, G. J., F. Cooke, R. I. Goudie, and W. S BOYD. 2000. Spacing patterns, mating systems, and winter philopatry in Harlequin Ducks. Auk 117:299-307.

Rosenberg, D. H., and M. J. Petrula. 1998. Status of Harlequin Ducks in Prince William Sound, Alaska, after the Exxon Valdez oil spill, 1995-97. Exxon Valdez Oil Spill Restoration Project Final Report (Restoration Project 97427), Alaska Dept. Fish Game, Div. Wildl. Conserv., Anchorage, AK. Schmutz, J. A., R. F. Rockwell, And M. R. Petersen. 1997. Relative effects of survival and reproduc- 
tion on population dynamics of Emperor Geese. J. Wildl. Manage. 61:191-201.

Smith, C. M., F. Cooke, G. J. Robertson, R. I. GouDIE, AND W. S. BOYD. 2000. Long-term pair bonds in Harlequin Ducks. Condor 102:201-205.

Trust, K. A., D. Esler, B. R. Woodin, And J. J. SteGEMAN. 2000. Cytochrome P450 1A induction in sea ducks inhabiting nearshore areas of Prince William Sound, Alaska. Marine Poll. Bull. 40: 397-403.

Vermeer, K. 1983. Diet of the Harlequin Duck in the
Strait of Georgia, British Columbia. Murrelet 64: 54-57.

Wiens, J. A., AND K. R. PARKER. 1995. Analyzing the effects of accidental environmental impacts: approaches and assumptions. Ecol. Appl. 5:10691083.

Wolfe, D. A., M. J. Hameedi, J. A. Galt, G. WataBayashi, J. Short, C. O'Clair, S. Rice, J. MichEl, J. R. Payne, J. Braddock, S. Hanna, and D. SALE. 1994. The fate of the oil spilled from the Exxon Valdez. Environ. Sci. Technol. 28:561-568.

\title{
INFLUENCE OF FEMALE AGE AND BODY MASS ON BROOD AND DUCKLING SURVIVAL, NUMBER OF SURVIVING DUCKLINGS, AND BROOD MOVEMENTS IN REDHEADS ${ }^{1}$
}

\author{
TINA YERKES ${ }^{2}$ \\ Department of Zoology, University of Manitoba, Winnipeg, MB R3T 2N2, Canada
}

\begin{abstract}
I documented brood and duckling survival, the number of surviving ducklings, and brood movements of Redheads, and examined the association between these variables and female age and body mass. Redhead brood success was 55\% and duckling daily survival rates averaged 0.868 . Female body mass, but not age, was related to brood and duckling survival and the number of surviving ducklings. Successful females were heavier and produced more ducklings. All brood-movement measures differed between successful and unsuccessful females, however, the distance of the first move between wetlands accounted for the most variability in brood success. Increased body mass, but not age, was associated with longer first brood movements.
\end{abstract}

Key words: Aythya americana, body mass, brood movements, brood survival, duckling survival, female age, Redhead.

Although North American Anatinae produce precocial young, females provide post-hatch care. Poor or reduced brood care may result in lower brood or duckling survival (Talent et al. 1983). Among ducks, several factors may affect individual variation in brood care: temporal variation, brood age and size, and adult

\footnotetext{
${ }^{1}$ Received 22 July 1999. Accepted 4 April 2000.

${ }^{2}$ Current Address: Ducks Unlimited, Inc., Institute for Wetland and Waterfowl Research, One Waterfow Way, Memphis, TN 38120-2351, e-mail: tyerkes@ ducks.org
}

age and body mass. Older parents, as compared to yearlings, should maximize fitness by exhibiting greater parental investment (PI) (Trivers 1974). Older parents may also benefit from experience gained through raising previous broods, and thus have higher brood success than younger parents. Afton (1984) provided weak support for increased PI with age in Lesser Scaup (Aythya affinis) because the amount of time females spent in brood care increased with age to a point. Female age did not influence brood survival in Lesser Scaup (Afton 1984) or Canvasbacks (Aythya valisineria) (Serie et al. 1992).

Female body mass may further influence variation in PI and has been shown to influence incubation (Gloutney and Clark 1991, Yerkes 1998) and brood adoption or abandonment (Kehoe 1986) in ducks. Only one study, however, examined the relationship between female body mass and brood survival, but detected no relationship of these variables in Canvasbacks or Redheads (Aythya americana) (Arnold et al. 1995).

Brood movements among wetlands may affect brood survival and could be influenced by female age and body mass, although these have not been examined to date. Females may move their broods in response to low invertebrate numbers or to avoid wetlands lacking a zone of emergent vegetation. Results from studies examining the relationship between brood movements and brood survival are conflicting: some demonstrate a negative relationship (Rotella and Ratti 1992a), whereas others found a positive or no relationship (Mauser et al. 1994).

Little is known about Redhead brood survival or 
brood movements. Redheads are interesting because they frequently engage in nest parasitism prior to nesting. This behavior, known as a dual strategy (Sorenson 1990), may be energetically costly and therefore influence subsequent PI and brood success due to decreased body condition. Elsewhere I have demonstrated that Redheads exhibit lower PI, in the form of incubation constancy, compared to other ducks of similar body size (Yerkes 1998). Furthermore, among conspecifics, Redheads with lower body mass exhibit lower incubation constancy than heavier females (Yerkes 1998) These tendencies could ultimately result in decreased brood and duckling survival and subsequent recruitment in Redheads. Therefore the objectives of this study were first to document brood and duckling survival, the number of surviving ducklings, and brood movements. Secondly, the objectives were to determine how these parameters are affected by age and body mass of brood rearing females.

\section{METHODS}

I conducted this study in southwestern Manitoba $\left(50^{\circ} 15^{\prime} \mathrm{N}, 99^{\circ} 50^{\prime} \mathrm{W}\right.$ ) in 1994 and 1995 (see Stoudt 1982 for study site description). Habitat conditions were good for diving ducks in both years of this study. I trapped female Redheads on nests between 22 and 24 days of incubation, aged (Dane and Johnson 1975), weighed ( $\pm 5 \mathrm{~g}$ ), and surgically implanted radio transmitters. Surgical procedures followed Korshgen et al. (1984).

I located females with broods daily with either a truck-mounted 2-antenna, 4-element system, or by 3element hand held antennae. I counted daily the number of ducklings per brood or as often as they were sighted. On two occasions, ducklings were not counted because emergent cover restricted visibility. I monitored broods for a maximum of 30 days post-hatch or until all ducklings in a brood died.

A brood was considered successful if at least one duckling survived 30 days (Klett et al. 1986). Brood survival was determined as the proportion of broods that survived to 30 days. Duckling survival was estimated using a modified Mayfield method (Flint et al. 1995). Daily survival rates (DSR) for ducklings were estimated for two periods, $<8$ days and 8-30 days, because high mortality occurs early in brood rearing (Mauser et al. 1994, Guyn and Clark 1999). The 30day survival estimate was the product of the survival estimates for the two periods (Johnson 1979). The last known number of ducklings was used as a measure of the number of surviving ducklings from a brood. used this number as a relative comparison of brood size among females because one egg from each clutch was removed as a part of another study (Yerkes 1998).

I measured brood movements on aerial photographs as straight-line distances between the centers of wetlands used by broods. A brood movement was considered to have occurred only when a brood was observed on a new wetland or, in the case of $100 \%$ emergent cover, when a female remained on the wetland for at least three consecutive days. Occasionally, females left broods unattended and flew to nearby wetlands, but these movements were not considered.

\section{DATA ANALYSIS}

I examined the influence of female age, body mass, and hatch date on brood survival, duckling DSRs $(<8$ day, 8-30 day, and 30-day), and the number of ducklings with a general linear model (PROC GLM) (SAS Institute 1989) for main effects and possible interactions. I examined brood movements for possible correlation (PROC CORR) and compared movements between successful and unsuccessful females with $t$-tests (PROC TTEST). Because all brood movements were highly correlated, a backward stepwise discriminant analysis procedure (PROC STEPDISC) was used to determine which of the brood movement measures accounted for the most variability between successful and unsuccessful females. A general linear model (PROC GLM) was used to determine the influence of age and body mass on brood movements identified by discriminant analysis. Values reported are means \pm SE.

\section{RESULTS}

Forty broods were monitored from hatch to $\leq 30$ days in $1994(n=12)$ and $1995(n=28)$. Brood survival was $55 \%(n=40)$, and the average number of surviving ducklings was $4.2 \pm 0.4(n=36$, range 0 to 9$)$. DSR for 30 days was 0.870 , and DSR for older ducklings (8-30 day) $(0.971 \pm 0.054, n=29)$ was higher than younger ducklings $(<8$ day) $(0.896 \pm 0.035, n=$ 34) $\left(\chi^{2}{ }_{1}=19.4, P<0.001\right)$. Hatch dates ranged from 10 June to 21 July in 1994 and 18 June to 28 July in 1995 , and were not significantly different between yearling $(n=16)$ and adult females $\left(n=24 ; t_{38}=0.6\right.$, $P>0.50$ ). Undetermined predators killed two females and two other broods could not be observed.

Only female body mass influenced brood survival in a model that examined the effect of age, body mass, and hatch date $\left(F_{1,39}=5.2, P<0.05\right)$; although the overall fit of the model was low $\left(R^{2}=0.13\right)$. All interactions in this model were insignificant and deleted from the model. Body mass of successful brood-rearing females $(937.7 \pm 12.3 \mathrm{~g}$, range $840-1,090, n=$ 22) was higher than unsuccessful females $(903 \pm 11.5$ $\mathrm{g}$, range $810-990, n=18$ ). Body mass also was the only significant main effect in models examining the influence of age, body mass, and hatch date on duckling number $\left(F_{1,38}=10.1, P<0.01\right),<8$ day DSR $\left(F_{1,33}=4.9, P<0.05\right)$, and 30 day DSR $\left(F_{1,34}=4.0\right.$, $P=0.05)$. Neither age, body mass, nor hatch date influenced 8-30 day DSR. Again, interactions were not detected. For successful females, the number of surviving ducklings tended to increase with increasing female body mass (Fig. 1a). The number of ducklings observed within one week of hatch was not correlated with female body mass $\left(r_{\mathrm{s}}=0.3, n=38, P>0.05\right)$.

The average number of brood movements $(2.5 \pm$ 0.3 , range $0-9)$, distance of the first move $(0.2 \pm 0.03$ $\mathrm{km}$, range $0-0.7)$, longest distance moved $(0.4 \pm 0.04$ $\mathrm{km}$, range 1-1.1), and total distance moved $(0.8 \pm 0.1$ $\mathrm{km}$, range 0-3.6) were all positively and significantly correlated (all $r \geq 0.42$, all $P<0.01$ ). All brood movements differed between successful and unsuccessful females. In backward stepwise discriminant analysis, the distance of the first move accounted for the most variation in survival $\left(R^{2}=0.08, F_{1,37}=3.4, P>0.07\right)$, 

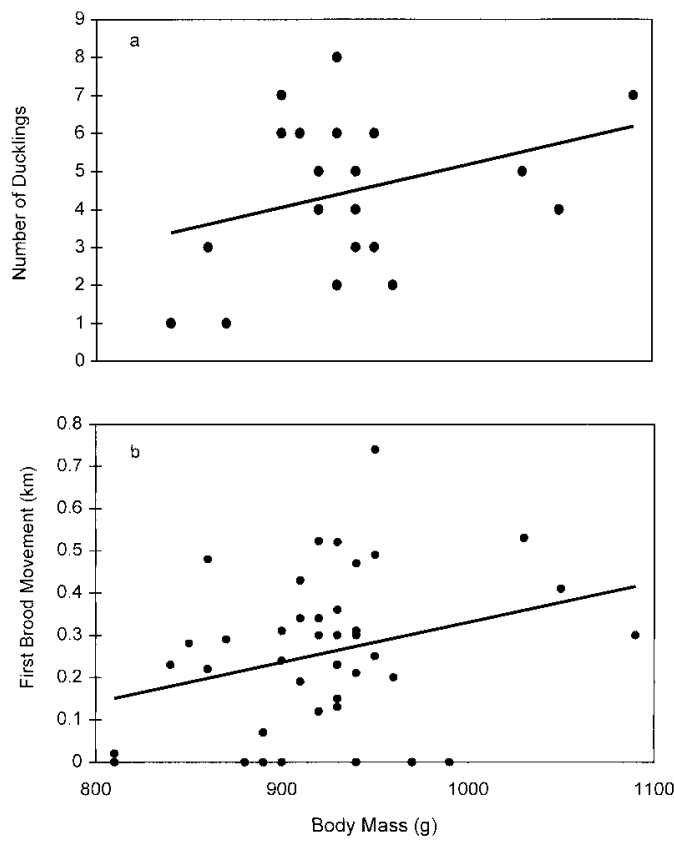

FIGURE 1. (a) Relationship between female body mass and number of surviving ducklings for successful brood rearing female Redheads $(n=22)$ and (b) relationship between distance of the first brood movement and body mass of female Redheads $(n=40)$. Sold lines represent the predicted relationships.

whereas no movement measures were significant in a similar model with number of ducklings as the dependent variable. In a full model with the distance of the first brood movement as the dependent variable, only body mass was significant $\left(F_{1,39}=4.9, P<0.05\right)$. The distance of the first brood movement increased with female body mass at hatch (Fig. 1b).

\section{DISCUSSION}

Redhead brood and duckling survival are associated with female body mass and brood movements, but not female age or hatch date. In Redheads, post-hatch PI may be influenced by pre-hatch reproductive effort, therefore age may be a complicating factor due to the parasitic tendencies of this species. Sorenson (1990) demonstrated that older females were more likely to invest in a dual reproductive strategy, which may be more energetically costly. Reproductive strategy choice may further be influenced by body mass (Sorenson 1990, Yerkes and Koops 1999), such that older, heavier females may invest more in pre-hatch reproductive effort and begin brood rearing at weights similar to females that only nested. Therefore, due to the variety of reproductive strategies available to Redheads, older females may invest heavily in pre-hatch reproductive costs and may not exhibit the age-related brood survival that has been observed in other duck species (Blums et al. 1997).

Studies on Mallards (Anas platyrhynchos) (Mauser et al. 1994), Buffleheads (Bucephala albeola) (Savard et al. 1991), and now Redheads, found no relationship between hatch date and brood survival. Others, however, have documented lower survival of late-hatched broods (Rotella and Ratti 1992b, Guyn and Clark 1999). This relationship is sometimes associated with younger females nesting later in the season, but this explanation cannot apply to Redheads in this study, nor in Sorenson's (1990), because adult and yearling hatch dates were not significantly different.

Females that were heavier at the end of incubation had higher brood survival and produced more ducklings per brood than lighter females. This result is not due to heavier females initially producing more eggs and thus hatching more ducklings because I did not detect a relationship between body mass at the end of incubation and the number of ducklings that hatched. My results contrast with those of Arnold et al. (1995) who demonstrated that late incubation body mass was unrelated to brood and duckling survival in Redheads and Canvasbacks. It may be that females in better condition at the end of incubation devote more time to brood care activities than females that weigh less. Lighter females may be required to devote a significant amount of brood rearing time to self maintenance, particularly during the early part of brood rearing $(<8$ days) when body mass significantly influenced duckling daily survival rates. No time budget studies have been reported for females in varying body condition states during brood rearing. One study, however, illustrated that brood rearing females devote about $50 \%$ of their time to self maintenance (mostly feeding) and that females with broods spend less time feeding than females without broods (Afton 1984). Body condition likely influences amount of time spent feeding by females during brood rearing especially during the time immediately following hatch when female body mass is lower than any other time of the year (Alisauskas and Ankney 1992).

My results suggest that brood movements are important to Redhead brood survival. Brood movements are common among ducks and often influence brood survival. Typically, the greatest distances moved by ducklings occur within the first week post-hatch (Rotella and Ratti 1992a); a finding similar for Redheads in this study given that the first distance moved was often the longest. In Mallards, brood movement distances were negatively correlated with survival (Rotella and Ratti 1992b). For broods moving shorter distances, median duckling survival was higher (Rotella and Ratti 1992b). In contrast, some studies did not detect a relationship between survival and overland movements by broods (Mauser et al. 1994).

Measures of brood movements differed between successful and unsuccessful female Redheads: successful females moved more often, made longer first moves, executed longer moves in general, and moved greater total distances than unsuccessful females. Total number and distance of movements are probably greater by virtue of the broods of successful females surviving more days than those of unsuccessful females; however, distance of the first brood movement was an important factor influencing survival. The influence of brood movements on brood survival is equivocal. For 
example, movements of Mallard broods were negatively correlated with survival and the number of ducklings that survived (Rotella and Ratti 1992b), but I detected the opposite relationship in Redheads in which the first distance moved enhanced brood survival. This pattern may reflect a strong preference for specific types (Yerkes, in press) or conditions of wetlands by Redheads even though it requires longer overland movements to reach them, thus potentially suggesting that Redheads may have more specialized habitat requirements than Mallards. Additionally, body mass is associated with movements, although female age is not. Females that are heavier at the end of incubation traveled farther during the first brood movement than lighter females. Again, this may reflect preference for specific wetlands and the ability to reach them by virtue of better body condition.

R. Sayler and B. Davis provided helpful editorial comments. I thank the numerous field assistants that helped collect data, especially S. Badzinski, J. Leo, M. Brasher, N. Dion, M. Gendron, B. Mense, G. Peroff, C. Reinke, and A. Selle. This research was funded by the Delta Waterfowl Foundation.

\section{LITERATURE CITED}

Afton, A. D. 1984. Influence of age and time on reproductive performance of female Lesser Scaup. Auk 101:255-265.

Alisauskas, R. T., And C. D. Ankney. 1992. The cost of egg laying and its relationship to nutrient reserves in waterfowl, p. 30-61. In B. D. J. Batt, A. D. Afton, M. G. Anderson, C. D. Ankney, D. H. Johnson, J. A. Kadlec, and G. L Krapu [EDS.], Ecology and management of breeding waterfowl. Univ. Minnesota Press, Minneapolis, MN.

Arnold, T. W., M. G. Anderson, R. B. Emery, M. D. Sorenson, and C. N. DeSobrino. 1995. The effect of late-incubation body mass on reproductive success of Canvasbacks and Redheads. Condor 97:953-962.

Blums, P., G. R. Hepr, and A. Mednis. 1997. Agespecific reproduction in three species of European ducks. Auk 114:737-747.

Dane, C. W., and D. H. Johnson. 1975. Age determination of female Redhead ducks. J. Wildl. Manage. 39:256-263.

Flint, P. L., K. H. Pollock, D. Thomas, and J. S. SEDINGER. 1995. Estimating prefledging survival: allowing for brood mixing and dependence among brood mates. J. Wildl. Manage. 59:448-455

Gloutney, M. L., and R. G. Clark. 1991. The significance of body mass to female dabbling ducks during late incubation. Condor 93:811-816.

GuYn, K. L., AND R. G. Clark. 1999. Factors affecting survival of Northern Pintail ducklings in Alberta. Condor 101:369-377.

Johnson, D. H. 1979. Estimating nest success: the Mayfield method and an alternative. Auk 96:651661.

KeHoE, F. P. 1986. The adaptive significance of creching behavior in the White-winged Scoter. M.Sc. thesis, Univ. Guelph, Ontario, Canada.

Klett, A. T., H. F. Duebbert, C. A. Faanes, and K. F. Higgins. 1986. Techniques for studying nest success of ducks in upland habitats in the prairie pothole region. U.S. Fish and Wildl. Serv. Resour. Publ. 158, Washington, DC.

Korshgen, C. E., S. J. Maxson, and V. B. Kuechle. 1984. Evaluation of implanted transmitters in ducks. J. Wildl. Manage. 48:982-987.

Mauser, D. M., R. L. JARVIS, AND D. S. GILMER. 1994. Survival of radio-marked Mallard ducklings in northeastern California. J. Wildl. Manage. 58:8287.

Rotella, J. J., AND J. T. RatTi. 1992a. Mallard brood movements and wetland selection in southwestern Manitoba. J. Wildl. Manage. 56:508-515.

Rotella, J. J., AND J. T. RATTI. 1992b. Mallard brood survival and wetland habitat conditions in southwestern Manitoba. J. Wildl. Manage. 56:499-507.

SAS InSTITUTE InC. 1989. SAS/STAT user's guide, Version 6, 4th ed. SAS Institute, Inc., Cary, NC.

Savard, J. L., G. E. John SMith, AND J. N. M. SMith. 1991. Duckling mortality in Barrow's Goldeneye and Bufflehead broods. Auk 108:568-577.

Serie, J. R., D. L Trauger, and J. E. Austin. 1992. Influence of age and selected environmental factors on reproductive performance of Canvasbacks. J. Wildl. Manage. 56:546-556.

Sorenson, M. D. 1990. Parasitic egg laying in Redhead and Canvasback ducks. Ph.D. diss., Univ. Minnesota, Minneapolis, MN.

Stoudt, J. H. 1982. Habitat use and productivity of Canvasbacks in southwestern Manitoba. 19611972. U.S. Fish Wildl. Serv. Spec. Sci. Rep. Wildl. No. 248, Washington, DC.

Talent, L. G., R. L. JaRvis, AND G. L. KRapU. 1983. Survival of Mallard broods in south-central North Dakota. Condor 85:74-78

Trivers, R. L. 1974. Parent-offspring conflict. Am. Zool. 14:249-264

Yerkes, T. 1998. The influence of female age, body mass, and ambient conditions on Redhead incubation constancy. Condor 100:62-68.

YERKES, T. In press. Nest site characteristics and brood habitat selection of Redheads: an association between wetland characteristics and success. Wetlands.

Yerkes, T., AND M. A. Koops. 1999. Redhead reproductive strategy choices: a dynamic state variable model. Behav. Ecol. 10:30-40. 